\title{
MECHANICAL, CHEMICAL AND MICROSTRUCTURE PROPERTIES OF COMPOSITE EDIBLE FILM ADDED WITH MODIFIED CASEIN
}

\author{
Mulia Winirsya Apriliyani ${ }^{1)}$, Ria Dewi Andriani ${ }^{1}$, Premy Puspitawati Rahayu ${ }^{1)}$, \\ Purwadi Purwadi ${ }^{1}$, Abdul Manab ${ }^{1)}$ \\ ${ }^{1)}$ Department of Animal Products Technology, Faculty of Animal Science, Universitas Brawijaya, Jl. Veteran, \\ Ketawanggede, Kec. Lowokwaru, Malang City, East Java, Indonesia, 65145 \\ Email: muliaapriliyani@ub.ac.id
}

Submitted 25 August 2020; Accepted 10 October 2020

\begin{abstract}
Edible film is potentially applied to replace non-biodegradable packaging for animal products, e.g. meat and meat products. The overall objective of this study was to observe the effect of different addition levels of modified casein hydrolysate (casein-catechin complexes) on mechanical (film thickness, water vapor permeability, tensile strength, elasticity), chemical (moisture content, water activity, and solubility) and microstructure properties of composite edible casein film. The edible films were formulated according to different combinations of modified casein hydrolysate and casein film solution (0.50:0.25, 0.50:0.50, 0.75:0.25, and 0.75:0.50) and compared with control (without addition of modified casein). No significant effects of the treatment were found on film thickness, water vapor permeability, tensile strength, elasticity, moisture content, water activity, and solubility of the composite edible film. However, the micrographs show that the amount of polymer was higher as the proportion of catechin was increased. In conclusion, the addition of catechin-added casein (modified casein) to casein edible film solution at up to $0.5 \%$ did not alter the mechanical properties, moisture content, water activity and solubility of the composite edible film.
\end{abstract}

Keywords: Biodegradable film; biopolymer; casein; catechin 


\section{INTRODUCTION}

Plastic packaging has unique properties as it can be used at a very wide range of temperature but can be easily worked as a hot melt. Issues polymeric materials of plastics and any associated safety (Andrady and Mike, 2009), these polymers have many disadvantages including cannot be destroyed naturally (non-biodegradable) causing pollution to the environment. Plastics are nonbiodegradable or few are degradable but in a very slow rate (Tripathi, Ahutosh, and Devendra Trapathi, 2016.). Organic packaging is needed from materials that can be recycled (renewable) at a price that is sufficiently and economical. Edible film is used to coat a product as a barrier against mass transfer such as humidity, oxygen, and light so that it can extend the shelf life (Shendurse et al., 2018).

Edible film, which is made from edible ingredients and has a function as a protector of physical changes in food products, is a biodegradable alternative to synthetic plastic for food (Cahyaningtyas et al., 2015). Casein is a milk protein which is used as ingredient in the manufacture of edible films. Caseins are soluble and can form films exhibiting resistance to denaturation and/or coagulation even at high temperature, and thus the protein film remains stable over a wide range of temperature, $\mathrm{pH}$ and salt concentrations. The film based on casein could be modified depending on environmental conditions (Shendurse et al., 2018).

The constituent of edible film can affect their physical and mechanical properties, usually composed of three main constituent groups consisting of hydrocolloids, lipids and composites

*Corresponding author:

Mulia Winirsya Apriliyani

Email: muliaapriliyani@ub.ac.id

Department of Animal Products Technology, Faculty of Animal Science, Universitas Brawijaya, Jl. Veteran, Ketawanggede, Kec. Lowokwaru, Malang City, East Java, Indonesia, 65145
(Bourtoom, 2008), developed to produce more hydrophobic casein through high pressure processing with $\mathrm{CO}_{2}$, producing casein films with considerably lower solubility (Tomasula, 2009). There are several food additives that can be added into edible film including antimicrobial, antioxidant, flavor and coloring agent (Shendurse et al., 2018). Along with the development of edible film technology, modified casein can be added in order to to carry mechanical and chemical agents to a food quality. This property allows edible film which used modified casein tend to shrink during drying, to extend food stability and to prevent surface contamination.

The fortification of bioactive components into edible films requires consideration of the final quality of edible film. Their important functionalities include mechanical protection, control of mass transfers and sensory properties (Shendurse et al., 2018). Additions were made with casein material modified with catechin compounds. The catechin extracted from cocoa husk inhibits oxidation and can be used to fortify dairy products (Rahayu et al, 2019). The interaction of casein with phenol compounds is influenced by many factors, one of which is the proline level in casein (Bohin et al., 2012). Polyphenols bind to casein through hydrophilic and hydrophobic interactions (Hasni et al., 2011). The interaction of polyphenols and proteins is dominated by non-covalent interactions, namely hydrophobic interactions stabilized by hydrogen bonds (Yuksel et al., 2010). The more hydroxyl $(\mathrm{OH})$ groups, the higher the binding of catechins to casein exists. The interaction of milk proteins with polyphenols induces structural casein changes (Hasni et al., 2011). The formation of casein-catechin complexes can be done

\footnotetext{
How to cite:
}

Apriliyani, M. W., Andriani., R. D., Rahayu, P. P., Purwadi, P., Manab, A. (2020). Mechanical, Chemical and Microstructure Properties of Composite Edible Film Added with Modified Casein. Jurnal Ilmu dan Teknologi Hasil Ternak, 15 (3), 162-171 
by adding the mixture into the bacteria growth inhibitor medium, i.e. edible film. Waty (2007) reported that edible whey protein films added with lipids can reduce water vapor permeability (WVP) because of the interactions between hydrophobic substances and emulsification between lipids and whey proteins in edible film emulsions. After modification, caseincatechin complexes are expected to have good mechanical and chemical qualities to optimize the function of edible film as barrier. Therefore, the objective of this study was to observe the effect of different addition levels of casein-catechin complexes on mechanical, chemical and microstructure quality of composite edible film.

\section{MATERIALS AND METHODS}

\section{Casein Modification}

The modified casein (MC) hydrolysate and extraction of catechin were prepared in the laboratory. Catechin was extracted from cocoa husk according to the method described by Rahayu et al. (2019). Casein hydrolysate powder $(2.5 \mathrm{~g})$ was mixed with $100 \mathrm{~mL}$ distilled water, and the $\mathrm{pH}$ was adjusted to 6.8 using phoshate buffer. After target $\mathrm{pH}$ was reached, the catechin extract was added at either $0.25 \%$ or $0.75 \%(\mathrm{w} / \mathrm{v})$ and stirred for $5 \mathrm{~min}$ at $40^{\circ} \mathrm{C}$.

\section{Edible Film Formulation}

Edible film was made according to a modified method by Manab (2008). Casein hydrolysate $(2.5 \mathrm{~g})$ was mixed with $100 \mathrm{~mL}$ phoshate buffer and stirred at $250 \mathrm{rpm}$ for $3 \mathrm{~h}$. Glycerol $(0.7 \mathrm{~mL})$, beeswax $(0.25 \mathrm{~g})$ and modified casein were added according to the treatment group (Table 1). The solution
$(25 \mathrm{~mL})$ was casted on the petridish and dried at $40^{\circ} \mathrm{C}$. The mechanical properties (film thickness, water vapor permeability, tensile strength, elongation at break, film solubility and microstructure of composite films) of the edible films were then analyzed.

\section{Film Thickness and Tensile Strength}

The thickness of edible film was measured using a calipers in three different locations. Tensile strength was measured according to the ASTM d638 standards (Cuq et al., 1996). Tensile strength instruments are turned on for $15 \mathrm{~min}$ to warm up. Turned $\mathrm{ON}$ the computer to enter the program the machine software. Tensile Strength Machine and the computer ensured a connection then a program will appear on the screen. Cursor placed on 'ZERO' and ' $\mathrm{ON}$ ' so that between the instruments and computer monitors show the number 0.0 at the time of testing. The sample is clamped with pulling accessories. Press the 'tension' button to withdraw the sample. Press the 'stop' button to stop when the sample is interrupted and the data is listed on monitor tensile strength instrument.

\section{Elasticity}

The elasticity of the films was measured according to Cuq et al. (1996). Samples were cut into $3 \times 7 \mathrm{~cm}$ size and clamped with towing accessories of the instrument (UPHG20, Tarno Grocki, Japan). The initial length was record and the elasticity of the sample was calculated using the following formula:

$$
\text { Elasticity }=\frac{\text { Extension }(\mathrm{cm})}{\text { Initial length }(\mathrm{cm})} \times 100 \%
$$

Table 1. Edible film formula

\begin{tabular}{lll}
\hline Treatment & Modified casein $(\mathrm{MC}, \%)$ & Edible film solution $(\%)$ \\
\hline Control & - & 1.00 \\
$0.25 \% \mathrm{MC} 1$ & 0.50 & 0.25 \\
$0.50 \% \mathrm{MC} 1$ & 0.50 & 0.50 \\
$0.25 \% \mathrm{MC} 2$ & 0.75 & 0.25 \\
$0.50 \% \mathrm{MC} 2$ & 0.75 & 0.50 \\
\hline
\end{tabular}




\section{Water Activity}

Measurement of water activity (Santoso, 2009) using the Aw meter (Water Activity hygropalm tipe HP23 rotronic). The instrument was calibrated by inserting $\mathrm{BaCl}_{2} \cdot 2 \mathrm{H}_{2} \mathrm{O}$ fluid and closing it for $3 \mathrm{~min}$ until the number on the reading scale becomes 0.9 . Samples weighed $1 \mathrm{~g}$. Samples were inserted and the appliance were closed awaited up to $3 \mathrm{~min}$.

After $3 \mathrm{~min}$, the Aw scale was read and recorded, nothing the temperature scale and the correction factor. If the temperature scale was above $20^{\circ} \mathrm{C}$, then the Aw scale reading was added as much as the excess temperature multiplied by the correction factor of 0.002 , as well as the temperature below $20^{\circ} \mathrm{C}$.

\section{Water Vapor Permeability}

A modified method by Perez-Gago and Krochta (1999) was used to determine the water vapor permeability (WVP). Edible films were printed with a diameter of $15.5 \mathrm{~cm}$ on the teflon plate. After drying, one sample without defect was cut from each edible film. Aquades $(6 \mathrm{~mL})$ was channeled into the flatbottom of the beaker glass cup through their lips. Edible film is sealed to the bottom of the cup with a ring using four symmetrical screws and placed around the cup roundabout. The cups are placed in a desiccator cabinet with a fan. The weight of the edible film is taken periodically until a constant state is reached and the WVP value was determined using following formula:

$$
\mathrm{WVP}=\frac{\text { the weight of edible film }(\mathrm{g}) \times \text { thickness of edible film }(\mathrm{mm})}{\text { the area expose of edible film }(\mathrm{m} 2) \times \text { the time of gain }(\mathrm{h}) \times \Delta \mathrm{P}(\mathrm{KPa})} \times 100 \%
$$

where, WVP $=$ water vapor permeability and $\Delta \mathrm{p}=$ pressure difference between the two sides of the film.

\section{Solubility of Edible Film}

The solubility of edible films was measured according to Ahmad et al. (2012). Edible films were cut into a size of $3 \times 2 \mathrm{~cm}$ then dried with filter paper at $105^{\circ} \mathrm{C}$ for $24 \mathrm{~h}$. Previously filter paper and samples were weighed separately, to determine the initial weight of the sample (W1).

The sample was put into a $50 \mathrm{~mL}$ centrifuge tube containing $10 \mathrm{~mL}$ of distilled water, then immersed for $24 \mathrm{~h}$ at room temperature and stirred slowly periodically using a shaker. The solution was filtered, then filter paper and insoluble film were dried using an oven at $105^{\circ} \mathrm{C}$ for $24 \mathrm{~h}$. The sample was weighed (W2) to determine dry material that is not soluble in water. Solubility was calculated using the following formula:

Solubility $(\%)=\frac{W 1-W 2}{W 1} \times 100 \%$

where, $\mathrm{W} 1$ = weight of the sample and $\mathrm{W} 2$ $=$ the sample was weighed

\section{Moisture content}

The principle in measuring moisture content is by drying the material in an oven at $105^{\circ} \mathrm{C}$ until a constant weight is achieved. Weight differences before and after drying represents the amount of evaporated moisture. The sample (1 g) was weighed, then placed on a dried dish. The samples were put into the oven at a temperature of $102.5^{\circ} \mathrm{C}\left( \pm 2.5^{\circ} \mathrm{C}\right)$ for $5 \mathrm{~h}$. The samples were then cooled down in the desiccator and weighed. Moisture content was calculated using the following formula:

Moisture content $(\%)=\frac{W 1-W 2}{W 1-W 0} \times 100 \%$ Where, Wo = Weight of petridish constan; $\mathrm{W} 1=$ Weight of sample + petridish, and W2 $=$ Weight of final sample.

\section{Microstructure}

The surface and internal structure of the films were evaluated using a scanning electron miscroscope (SEM) according to Kusumo (2011). The sample was put very 
thin evenly on the plate aluminum has two sides, then the sample was coated with a layer of metal powders in gold with a time of coating $30 \mathrm{~s}$. The sample were observed using SEM with voltage $15 \mathrm{kV}$ and $5000 \mathrm{x}$ magnification. The sample was put on the aluminum slides, then coated with a layer of gold with time of coating of $30 \mathrm{~s}$. The sample were observed using SEM with voltage $15 \mathrm{kV}$ and 5,000 times magnification.

\section{Statistical Analysis}

The data were analyzed using analysis of variance (ANOVA) to observe the effect of different treatments. No significant differences were observed.

\section{RESULTS AND DISSCUSION}

\section{Mechanical Properties}

Based on Table 2, the average number of the highest thickness at the treatment of $0.5 \%$ MC 1 was 0.0788 , and the lowest average number of thicknesses at the treatment of $0.5 \% \mathrm{MC} 2$ was $0.055 \mathrm{~mm}$. The average results of the highest thickness of composite edible film with the addition of $0.5 \% \mathrm{MC}$ were due to the addition of $0.5 \%$ catechins which could not coalesce and form crystals in the casein-catechin edible film matrix, this affected the thickness of the edible film produced. The higher the amount of crystal in the film matrix was formed, the thickness increased.

According to Lucida (2006), catechins have properties that are not easily soluble in cold water but are soluble in hot water and form yellow crystals when get dried. According to Park et al. (2004), the thickness of edible film is influenced by the mold area, the volume of solution and the total amount of solids in the solution. Maruddin et al. (2017) reported that wheybased edible films and casein with different types of plasticizers have thicknesses between $0.08 \pm 0.02$ to $0.10 \pm 0.02 \mathrm{~mm}$. The thickness of edible film affects the rate of water vapor, gases, and other volatile compounds. The thicker the edible film is produced, the higher the ability to inhibit the rate of gas and water vapor, so that the product's shelf life will be longer.

Based on Table 2, the highest average WVP number at $0.5 \% \mathrm{MC} 1$ treatment was 0.0147 g.mm $/ \mathrm{m}^{2} . \mathrm{h} . \mathrm{kPa}$, and the lowest average WVP number was $0.5 \%$ MC 2 at 0.0110 g.mm $/ \mathrm{m}^{2}$.h.kPa. The higher the percentage of MC used, the lower the WVP value of edible film was achieved. This is caused by the nature of semi-polar catechins. The higher the amount of catechins was added, the more hydrophobic edible films will be produced, which affects the decrease in WVP. There were no significant differences on the WVP for each treatment. The difference in WVP was not significant because the range of the addition of catechins used was too close. Al Awwaly et al. (2010) reported that using whey based ingredients with various concentrations of glycerol resulted in an average water vapor transmission rate of 0.0102 $0.0149 \mathrm{~g} / \mathrm{mm}^{2} / \mathrm{h}$. Research by Julianto et al. (2011) showed that the highest water vapor transmission rate was found in the treatment of sorbitol plasticizers without the addition of palmitic acid, which was $8.05 \mathrm{~g} / \mathrm{mm}^{2} / \mathrm{h}$.

Based on Table 2, the average number of the highest tensile strength in the treatment of $0.25 \%$ MC 2 was $19.6667 \mathrm{MPa}$, and the average number of the lowest tensile strength in the treatment of $0.5 \%$ MC 1 was $2.9667 \mathrm{MPa}$. The tensile strength results in $0.25 \%$ MC 2 are caused by the amount of catechins added. The average yield of low tensile strength was due to the use of plasticizers in the manufacture of edible films. This is supported by the opinion of Rodriguez et al. (2006) who mentioned that the use of plasticizers tends to reduce the tensile strength and increase the percentage of elongation in edible films because plasticizers can reduce the force between molecules and increase the mobility of the biopolymer chain. The result of the tensile strength value at $0.5 \%$ MC 2 was $4.1333 \mathrm{MPa}$, it is assumed that the addition of catechins increased the thickness of the edible film produced so that the increasing 
thickness reduced the tensile strength of the edible film. This shows that the tensile strength of the edible film produced is inversely proportional to thickness (Sinaga et al., 2013). The difference in the value of tensile strength that is not significant in the manufacture of composite edible films with the addition of nano casein-catechins due to differences in thickness. It can be seen from the average number of tensile strengths between treatments that are relatively not much different.

Based on Table 2, the highest average elasticity rate in the treatment of $0.25 \% \mathrm{MC}$ 1 was $35.5567 \%$, and the lowest average elasticity rate at the treatment of $0.5 \% \mathrm{MC} 1$ was $23.3333 \%$. Catechins have an active hydroxyl $(\mathrm{OH})$ group. The higher the concentration of catechins was used, the greater the number of $\mathrm{OH}$ groups in the matrix edible film was achieved. The $\mathrm{OH}$ group plays a role in increasing the mobility of the edible film matrix polymer chain and this can lead to increased elasticity or length of edible film. Rodriguez et al. (2006) explained that glycerol which contains a lot of hydroxyl $(\mathrm{OH})$ groups in the edible film matrix system, can increase the water vapor transmission rate and the extension of edible film. There were no significant differences on the elasticity among treatments because the range of the addition of catechins was too close. According to Santoso et al. (2016), the edible film extension ranged from $37.17 \%$ to $84.4 \%$. The results of the elasticity value in the manufacture of edible films with the addition of MC were between $23 \%$ and $35 \%$. The elasticity value indicates that the composite edible film is not easily broken and can be used as a packaging.
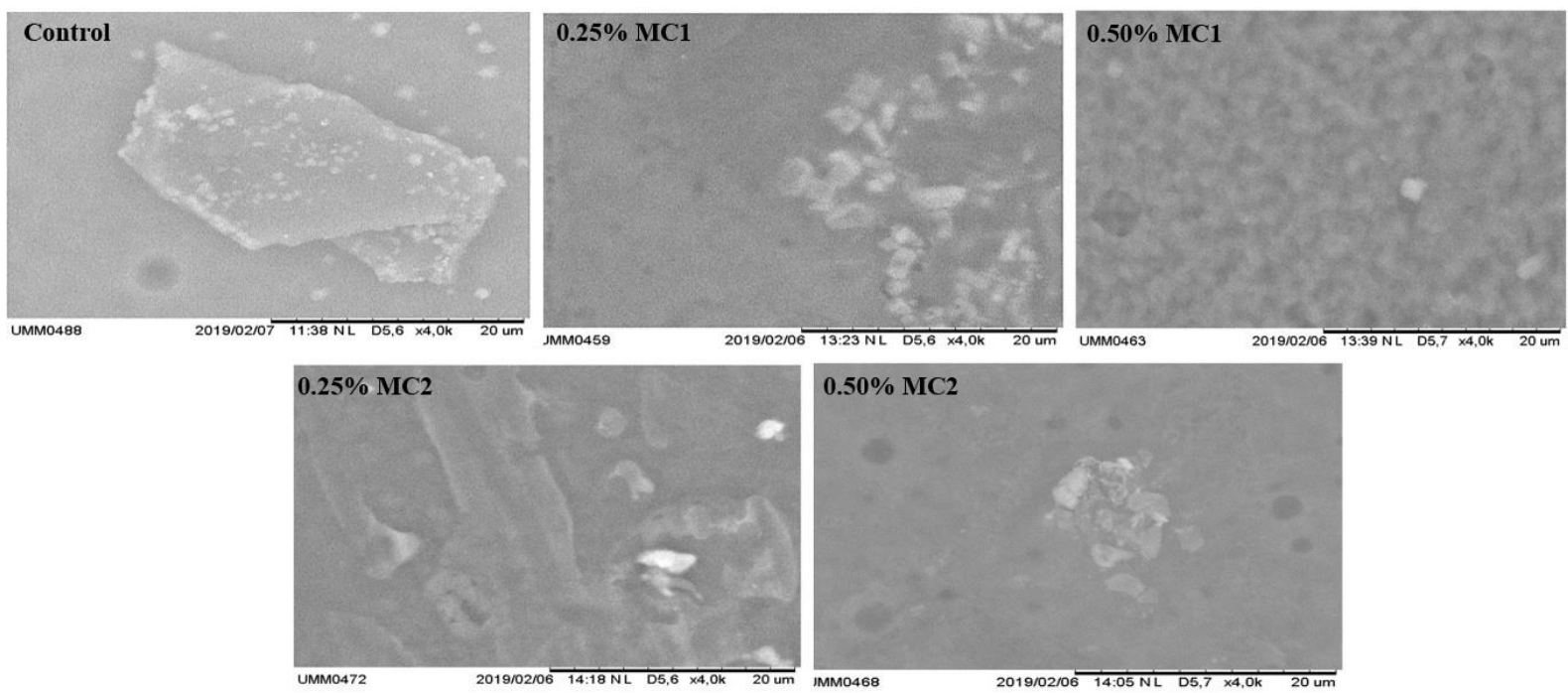

Figure 1. The micrograph of composite edible film added with modified casein

Table 2. The thickness, water vapor permeability (WVP), tensile strength and elasticity of edible films added with modified casein

\begin{tabular}{ccccc}
\hline $\begin{array}{c}\text { Treatment } \\
(\% \mathrm{MC})\end{array}$ & $\begin{array}{c}\text { Film Thickness } \\
(\mathrm{mm})\end{array}$ & $\begin{array}{c}\text { WVP } \\
\left(\mathrm{g} . \mathrm{mm} / \mathrm{m}^{2} . \mathrm{h} . \mathrm{kPa}\right)\end{array}$ & $\begin{array}{c}\text { Tensile strength } \\
(\mathrm{MPa})\end{array}$ & $\begin{array}{c}\text { Elasticity } \\
(\%)\end{array}$ \\
\hline Control & $0.082 \pm 0.012$ & $0.137 \pm 0.037$ & $3.03 \pm 1.01$ & $27.79 \pm 1.20$ \\
$0.25 \% \mathrm{MC} 1$ & $0.065 \pm 0.010$ & $0.012 \pm 0.010$ & $4.53 \pm 1.02$ & $35.56 \pm 8.38$ \\
$0.50 \% \mathrm{MC} 1$ & $0.078 \pm 0.003$ & $0.015 \pm 0.002$ & $2.97 \pm 1.41$ & $23.33 \pm 8.82$ \\
$0.25 \% \mathrm{MC} 2$ & $0.069 \pm 0.012$ & $0.014 \pm 0.006$ & $6.67 \pm 4.43$ & $28.89 \pm 18.95$ \\
$0.50 \% \mathrm{MC} 2$ & $0.055 \pm 0.038$ & $0.011 \pm 0.005$ & $4.13 \pm 1.95$ & $28.89 \pm 16.44$ \\
\hline
\end{tabular}

Note: $\mathrm{MC}=$ Modified casein

Values in the same column showed no significant differences $(p<0.05)$. 


\section{Chemical Properties}

Based on Table 3, the average number of the highest water content in the treatment of $0.5 \% \mathrm{MC} 1$ was $33.9267 \%$, and the average number of the lowest water content in the treatment of $0.25 \%$ MC 2 was $29.18 \%$. Increasing the percentage of catechins will increase the amount of polymer and viscosity that make up the film matrix. The larger the polymer that composes the film matrix will increase solids so that the amount of water in the edible film is lower. Putri and Ristia (2014) mentioned that larger polymer composing the film matrix causes lower amount of water left in the film. By increasing the viscosity, it will affect the thickness of the edible film and decrease the moisture content. The higher addition of the extract also increases the total dissolved solids in the edible film suspension. The total height of solids in edible film will directly affect the moisture content (Kusumawati and Putri, 2013). Mustapa et al. (2017) mentioned that edible films are biodegradable with high moisture content, easily contaminated by microbes due to the presence of nutritional compounds in the edible films. The moisture content of environmentally friendly films ranges from 16.48- $23.96 \%$. High film moisture content will affect the durability of the film (Mustapa et al., 2017). In contrast, edible films that have low water content will be more resistant to microbiological growth. The addition of catechin can increase carbohydrate, protein, and moisture content of edible coating (Apriliyani et al, 2020).

Based on Table 3, the highest $\mathrm{a}_{\mathrm{w}}$ value was 0.7087 for $0.25 \% \mathrm{MC} 1$ and the lowest $a_{w}$ value was 0.6867 for $0.5 \%$ CM 2. The lowest $\mathrm{a}_{\mathrm{w}}$ value are caused by the presence of $\mathrm{OH}$ groups in catechin structure which are reactive. The $\mathrm{OH}$ group can bind to water $\left(\mathrm{H}_{2} \mathrm{O}\right)$, so the higher the percentage of catechins added, the higher the binding capacity to water was achieved. More water was bound in the film matrix decreasing the $a_{w}$ value of edible film. According to Smith et al. (2003), the reactivity of catechin compounds was influenced by the number and configuration of hydroxyl groups in ortho positions of phenolic compounds. However, there were no significant differences on $\mathrm{a}_{\mathrm{w}}$ value among treatments. This was due to the storage of edible film. This is consistent with Rostini (2011) who did storage experiment and reported that the water content in food can change due to differences in humidity with the environment.

If food is stored in a more humid place, the food will absorb water. Conversely, if stored in a drier room it will vaporize some of the water. Catechins are compounds that are not stable against environmental influences including temperature and oxidation (Yeni et al., 2017).

The presented $a_{w}$ value in this study was low so that the edible film was not easily overgrown by microbes and possibly extends the shelf life of the coated products. The water activity of the edible whey protein composite films in this study ranged from 0.68 to 0.70 . The results of this study are still within the safe range of $a_{w}$ because it is below the range for the growth of spoilage bacteria. Various microorganisms have a minimum $a_{w}$ to grow well, for example bacteria have $a_{\mathrm{w}} 0.90$; yeast $0.80-0.90$; and molds can grow at $\mathrm{a}_{\mathrm{w}}$ of 0.60-0.70 (Belitz, Grosch, and Schieberle, 2009).

The highest solubility rate $(42.39 \%)$ was found on $0.25 \%$ MC 1 group, while the lowest $(22.95 \%)$ was found on $0.5 \% \mathrm{MC} 2$ group. The solubility of the edible film can be used as an indicator to measure water resistance, film integrity and capability. The solubility in water is an indication of a hydrophilicity of the edible film. Edible composite film added with catechin was not easily dissolved even though there were no significant differences. This is supported by the study of Lucida (2006) mentioned that catechins are not easily soluble in cold water, however, it is soluble in hot water and form yellow crystals when get dried. 
Table 3. Moisture content, water activity, and solubility of edible films added with modified casein

\begin{tabular}{cccc}
\hline Treatment $(\% \mathrm{MC})$ & Moisture content $(\%)$ & Water activity & Solubility $(\%)$ \\
\hline Control & $32.93 \pm 2.42$ & $0.71 \pm 0.01$ & $32.64 \pm 4.49$ \\
$0.25 \% \mathrm{MC} 1$ & $32.15 \pm 3.33$ & $0.71 \pm 0.02$ & $42.29 \pm 1.01$ \\
$0.50 \% \mathrm{MC} 1$ & $33.93 \pm 4.85$ & $0.70 \pm 0.03$ & $31.82 \pm 7.40$ \\
$0.25 \% \mathrm{MC} 2$ & $29.18 \pm 4.47$ & $0.70 \pm 0.02$ & $34.95 \pm 1.66$ \\
$0.50 \% \mathrm{MC} 2$ & $31.10 \pm 2.05$ & $0.69 \pm 0.02$ & $22.95 \pm 2.23$ \\
\hline
\end{tabular}

Note:

$\mathrm{MC}=$ Modified casein

Values in the same column showed no significant differences $(\mathrm{p}<0.05)$.

The insignificant difference in the average solubility rates in each treatment. It can be seen from the average solubility rate between treatments that are relatively not much different. The material for making edible film is protein molecules that are hydrophilic. This can cause the formation of complex bonds between protein molecules through active groups $\mathrm{NH}_{3}$ with catechin compounds through hydroxyl $(\mathrm{OH})$ groups. This bond causes the edible film matrix to have a high solubility. Solubility of edible film produced in this study is quite high, ranging from $22-42 \%$. The same solubility value was described by Pitak and Rakshit (2011) on composite banana flour and carrageenan edible films with a range of 40.90-64.21\%. Solubility value of edible film which is expected to not be easily degraded and can be used as primary packaging so that the coating on food is not easily damaged. High solubility causes edible film to dissolve easily in water and its ability to hold water is reduced.

\section{Microstructure}

The microstructure of the samples varied from rather flat to very uneven (Fig. 1). Unevenness and pore presence in the film were caused by the formation of a protein complex gel from casein and polysaccharides from edible film material. The control group had a beeswax lipid size that was difficult to fuse, in contrast to the $0.5 \% \mathrm{MC} 1$. The treatment with modified casein concentration of $0.5 \%$, the structure looks evener and not much hollow. The microstructure of edible film shows the edible film structure which has cavities that differ in size and number. The more cavities will tend to increase the WVP value and it is influenced by the solubility of the film. The characteristics of edible films made of chitosan was observed as smooth, compact, and without any crack or pores (Kaya et al., 2018). The morphology of edible films, which made of arabinoxylans films, sodium caseinate, starch, cellulose, and pea protein, had more roughness and irregular shape (Karabulutand and Mehmetoglu, 2018).

\section{CONCLUSION}

In conclusion, the use of different addition levels of casein-catechin complexes did not alter the mechanical properties, moisture content, water activity and solubility of the composite edible film. Further research is required to determine the effect of this casein-modified edible film on the shelf life of raw meat.

\section{REFERENCES}

Ahmad, M., Benjakul, S., Prodpran, T., \& Agustini, T. W. (2012). Physicomechanical and antimicrobial properties of gelatin film from the skin of unicorn leatherjacket incorporated with essential oils. Food Hydrocolloids, 28(1), 189-199. https://doi.org/10.1016/j.foodhyd.201 1.12 .003

Andrady, A. L., \& Neal, M. A. (2009). Applications and societal benefits of plastics. Philosophical Transactions 
of the Royal Society B: Biological Sciences, 364(1526), 1977-1984. https://doi.org/10.1098/rstb.2008.0304 Apriliyani, M. W., Rahayu, P. P., Andriani, R. D., Manab, A., Purwadi, Sawitri, M. E., \& Utama, D. T. (2020). Characteristics of casein-chitosan edible coating and its preservative effect in meat during accelerated storage. IOP Conference Series: Earth and Environmental Science, 478, 012060. https://doi.org/10.1088/17551315/478/1/012060

Apriliyani, M. W., Rosyidi, D., Purwadi, P., Purnomo, H., \& Manab, A. (2014). The release of egg white lysozyme containing EDTA from composite edible film based on whey protein, konjac flour and lipid. Advance Journal of Food Science and Technology, 6(1), 48-55. https://doi. org/10.19026/ajfst.6.3029

Awwaly, K. U. Al, Wahyuni, A. M. dan E., \& Manab, A. (2010). Pembuatan edible film protein whey: kajian rasio protein dan gliserol terhadap sifat fisik dan kimia. Jurnal Ilmu Dan Teknologi Hasil Ternak, 5(1), 45-56.

Bohin, M. C., Vincken, J.-P., van der Hijden, H. T. W. M., \& Gruppen, H. (2012). Efficacy of food proteins as carriers for flavonoids. Journal of Agricultural and Food Chemistry, 60(16), 4136-4143. https://doi.org/10. 1021/jf205292r

Bourtoom, T. (2008). Edible films and coating: characteristic and properties. International Food Research Journal, 15(3), 237-248.

Cuq, B., Gontard, N., Cuq, J.-L., \& Guilbert, S. (1996). Functional properties of myofibrillar protein-based biopackaging as affected by film thickness. Journal of Food Science, 61(3), 580-584. https://doi.org/10.11 11/j.1365-2621.1996.tb13163.x

Julianto, G., Ustadi, \& Husni, A. (2011). Characterization of edible film from red tilapia gelatin skin with the addition of plasticizer sorbitol and palmitic acid. Journal of Fisheries Sciences, 13(1), 27-34.

Karabulut, G., \& Cagri-Mehmetoglu, A. (2018). Antifungal, mechanical, and physical properties of edible film containing williopsis saturnus var. saturnus antagonistic yeast. Journal of Food Science, 83(3), 763-769. https:// doi.org/10.1111/1750-3841.14062

Kaya, M., Khadem, S., Cakmak, Y. S., Mujtaba, M., Ilk, S., Akyuz, L., Salaberria, A. M., Labidi, J., Abdulqadir, A. H., \& Deligöz, E. (2018). Antioxidative and antimicrobial edible chitosan films blended with stem, leaf and seed extracts of Pistacia terebinthus for active food packaging. RSC Advances, 8(8), 3941-3950. https://doi.org/10. 1039/C7RA12070B

Kusumawati, D. H., \& Putri, W. D. R. (2013). Physical and chemical characteristics of edible corn starch films incorporated with black gathering. Journal of Food and AgroIndustry, 1(1), 90-100.

Manab, A, Sawitri, M., \& Al Awwaly, K. U. (2017). Edible film Protein Whey. UB Press.

Manab, A. (2008). The effect of palm oil addition on the characteristics of whey protein edible films. Jurnal Ilmu Dan Teknologi Hasil Ternak, 3(2), 8-16.

Maruddin, F., Ako, A., \& Taufik, M. (2017). Characteristics of Edible film made from whey dangke and casein that uses different types of plasticizer. Jurnal Ilmu Dan Teknologi Peternakan, 5(2), 97-101.

Mustapa, R., Restuhadi, F., \& Efendi, R. (2017). Pemanfaatan kitosan sebagai bahan dasar pembuatan edible film dari pati ubi jalar kuning. Electronic Publishing, 4, 1-12.

Pérez-Gago, M. B., \& Krochta, J. M. (1999). Water vapor permeability of whey protein emulsion films as affected by pH. Journal of Food Science, 64(4), 695-698. https://doi.org/10.1111/j.13 65-2621.1999.tb15112.x 
Pitak, N., \& Rakshit, S. K. (2011). Physical and antimicrobial properties of banana flour/chitosan biodegradable and self sealing films used for preserving Fresh-cut vegetables. LWT - Food Science and Technology, 44(10), 2310-2315. https://doi.org/10.1016/j. lwt.2011.05.024

Rodríguez, M., Osés, J., Ziani, K., \& Maté, J. I. (2006). Combined effect of plasticizers and surfactants on the physical properties of starch based edible films. Food Research International, 39(8), 840-846. https:// doi.org/10.1016/j.foodres.2006.04.002

Rostini, I. (2011). Development of Edible Coating on Boiled Shrimp Made from Surimi Waste Red Snapper Filet Fish (Lutjanus sp.). Graduate School of Institut Pertanian Bogor.

Rahayu, P. P., Rosyidi, D., Purwadi, \& Thohari, I. (2019). Characteristics of catechin extracted from cocoa husks using microwave assisted extraction (MAE). Biodiversitas Journal of Biological Diversity, 20(12). https:// doi.org/10.13057/biodiv/d201222

Shendurse, A. (2018). Milk protein based edible films and coatings-preparation, properties and food applications. Journal of Nutritional Health \& Food Engineering, 8(2), 219-226. https:// doi.org/10.15406/jnhfe.2018.08.00273

Sinaga, L. L., Rejekina, M. S., \& Sinaga, M. S. (2013). Karakteristik edible film dari ekstrak kacang kedelai dengan penambahan tepung tapioka dan gliserol sebagai bahan pengemas makanan. Jurnal Teknik Kimia USU, 2(4), 12-16. https://doi.org/10.32734 /jtk.v2i4.1485

Susanto, A. (2009). Correlation test of water content, ash content of water activity and organic material on corn at the farmers, collector and wholesaler levels. National Seminar on Animal Husbandry and Veterinary Technology, 826-836.

Tomasula, P. M. (2009). Using dairy ingredients to produce edible films and biodegradable packaging materials. In Dairy-Derived Ingredients (pp. 589-624). Elsevier. https://doi.org/10.1533/97818456971 98.3.589

Tripathi, S, A., Yadav, \& Trapathi, D. M. (2016). Bioremediation of Industrial Pollutants. Write and Print Publications New Delhi.

Ye, J., Fan, F., Xu, X., \& Liang, Y. (2013). Interactions of black and green tea polyphenols with whole milk. Food Research International, 53(1), 449455. https://doi.org/10.1016/j.foodres. 2013.05.033

Yeni, G., Syamsu, K., Mardliyati, E., \& Muchtar, H. (2017). Determination of process technology on making of pure gambier and standardized catechin from raw gambier. Jurnal Litbang Industri, 7(1), 1-10. 